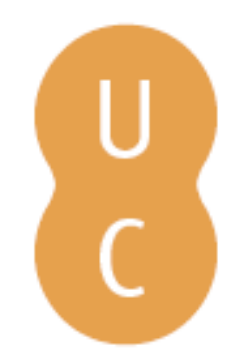

\title{
pommalina
}

\section{Global generation of long-term burned area with AVHRR-LTDR data}

Autor(es): $\quad$ Otón, Gonzalo; Ramo, Rubén; Lizundia-Loiola, Joshua; Chuvieco, Emilio

Publicado por: Imprensa da Universidade de Coimbra

URL

persistente: URI:http://hdl.handle.net/10316.2/44698

DOI: $\quad$ DOI:https://doi.org/10.14195/978-989-26-16-506_181

Accessed : $\quad$ 26-Apr-2023 13:14:50

A navegação consulta e descarregamento dos títulos inseridos nas Bibliotecas Digitais UC Digitalis, UC Pombalina e UC Impactum, pressupõem a aceitação plena e sem reservas dos Termos e Condições de Uso destas Bibliotecas Digitais, disponíveis em https://digitalis.uc.pt/pt-pt/termos.

Conforme exposto nos referidos Termos e Condições de Uso, o descarregamento de títulos de acesso restrito requer uma licença válida de autorização devendo o utilizador aceder ao(s) documento(s) a partir de um endereço de IP da instituição detentora da supramencionada licença.

Ao utilizador é apenas permitido o descarregamento para uso pessoal, pelo que o emprego do(s) título(s) descarregado(s) para outro fim, designadamente comercial, carece de autorização do respetivo autor ou editor da obra.

Na medida em que todas as obras da UC Digitalis se encontram protegidas pelo Código do Direito de Autor e Direitos Conexos e demais legislação aplicável, toda a cópia, parcial ou total, deste documento, nos casos em que é legalmente admitida, deverá conter ou fazer-se acompanhar por este aviso. 


\section{ADVANCES IN}

\section{FOREST FIRE RESEARCH}

\section{8}

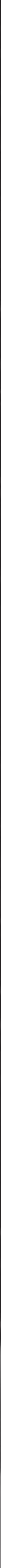


Short contribution - Decision Support Systems and Tools

Global generation of long-term burned area with AVHRR-LTDR data

Gonzalo Otón*, Rubén Ramo, Joshua Lizundia-Loiola, Emilio Chuvieco

Department of Geology, Geography and the Environment, Universidad de Alcalá, Spain \{gonzalo.oton@uah.es*; ruben.ramo@uah.es; joshua.lizundia@uah.es; emilio.chuvieco@uah.es\}

Keywords: Remote sensing, Burn area, AVHRR-LTDR, Multitemporal, Random Forest.

\section{Introduction}

Burned Area (BA) information is critical to assess the impacts of biomass burning, both in atmospheric emission models and dynamic vegetation studies (Hantson et al. 2016). Therefore, the fire variable is inside of Essential Climate Variables (ECV) for the Global Climate Observing System (GCOS) program. This work is part of the Fire Disturbance project, part of the Climate Change Initiative (CCI) Programme of the European Space Agency (ESA).

Current global burned area products expand from 1995 to 2017, being consistent as of 2001 (Mouillot et al. 2014). Longer time series would be desirable to analyze the impacts of climate cycles. This paper presents the development of a global BA algorithm adapted to Land Long-Term Data Record (LTDR, version 5, Pedelty et al. 2007), a time series based on NOAA-AVHRR (Advanced Very High Resolution Radiometer) data that covers the period from 1982 to 2017.

\section{Methods}

\subsection{LTDR and composites}

The LTDR is based on images acquired by the AVHRR sensor on board the NOAA satellites from 1981 until the present. This dataset includes atmospheric and geometric corrections of AVHRR data and provides daily thermal and reflectance values at $0.05^{\circ}(\approx 5 \mathrm{~km})$ of spatial resolution (Pedelty et al. 2007). As LTDR daily images present noise, radiometric instability and distortion, monthly composites were created by selecting the most adequate observation for burned area discrimination. The criterion to create the composites was based on selecting the maximum temperature of the period. This method improves the burn pixel separability and avoids clouds and shadows. (Chuvieco et al. 2005).

In addition, the unburnable areas were masked out with information derived from the CCI Land Cover product (Version 1.6.1., Kirches et al. 2013).

\subsection{MCD64}

The MCD64A1 dataset (Collection 6, Giglio et al. 2009) is generated through MODIS images from it is available (2001-present). The dataset is used to train the model as reference BA.

\subsection{Synthetic index}

A synthetic index was created from the different spectral bands (RED, NIR, Temperature channel 5), derived indices (GEMI, BAI) and temporal differences. The input bands were selected based on their spectral discriminability between burned and unburned areas. The final formula is: 


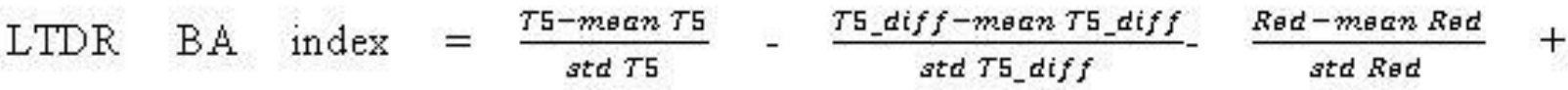

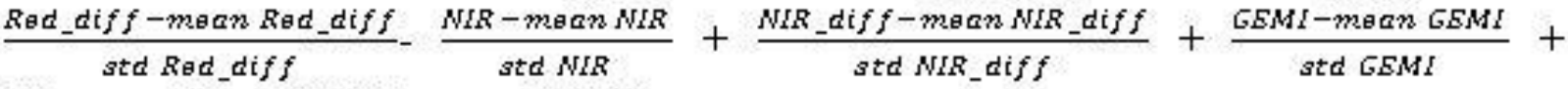

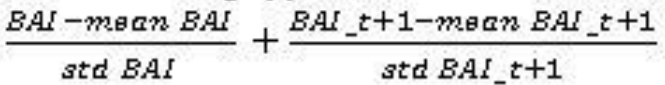

where

T5 = TOA brightness temperature of Channel $5(\sim 11.5-12.5 \mu \mathrm{m})$

$\mathrm{T} 5 \_$diff $=\mathrm{T} 5_{\mathrm{t}-1}-\mathrm{T} 5_{\mathrm{t}}$, where $\mathrm{t}=$ monthly composite being analyzed, and $\mathrm{t}-1=$ composite of the previous month.

Red $=$ Surface reflectance of Channel $1(0.5-0.7 \mu \mathrm{m})$

Red_diff $=\operatorname{Red}_{\mathrm{t}-1}-\operatorname{Red}_{\mathrm{t}}$

NIR = Surface reflectance of Channel $2(0.7-1.0 \mu \mathrm{m})$

NIR_diff $=$ NIR $\mathrm{t}_{-1}-\mathrm{NIR}_{\mathrm{t}}$

GEMI (Global Environmental Monitoring Index, Pinty and Verstraete 1992) as:

$$
G E M I=\eta^{*}(1-0,25 \eta)-\frac{\rho_{R}-0,125}{1-\rho_{R}} \quad \eta=\frac{2^{*}\left(\rho_{I R}^{2}-\rho_{R}^{2}\right)+\left(1,5^{*} \rho_{I R}\right)+\left(0,5^{*}, \rho_{R}\right)}{\rho_{I R}+\rho_{R}+0,5}
$$

Being $\rho_{R}$ and $\rho_{I R}$ the reflectivity in the red and infra-red bands, respectively.

BAI, the Burned Area Index (Martín and Chuvieco 1998):

$$
B A I=l /\left(\left(\rho_{R}-\rho_{R}\right)^{2}+\left(\rho_{R}-\rho_{R}\right)^{2}\right)
$$

where $\rho_{\mathrm{cIR}}$ and $\rho_{\mathrm{cR}}$ are the convergence values for burned vegetation (defined for AVHRR as 0.06 and 0.1 , respectively).

$\mathrm{BAI}_{t+1}$ is the BAI of the posterior monthly composite.

Seasonal variation of this index was also taken into account for training. So, the phenology variability is represented in the different months.

\subsection{Random Forest}

Random Forest (RF, Breiman 2001) is a machine-learning classifier based on a random combination of decision trees. RF classified each pixel by the number of times that pixel is assigned to a particular category. In our case, 600 trees were created for each monthly model (from January to December). RF models were created combining monthly composites of LTDR data from several years (both with high and low fire occurrence). Then, they were applied to the full-time series, a different model for each month of the year.

The output of RF was a probability per month and year.

\subsection{Sensitivity analysis and percentage}

Since the burned pixels are much more unlikely than the unburned, we performed a sensitivity analysis to obtain the appropriate cut-off threshold to improve overall accuracy and balance between omission and commission errors. Uncertainty information was estimated from the probability of RF.

A temporal analysis of the pixels that are burned in the MCD64 every month and its percentage was made. A value was assigned to each pixel per month and applied to the result of the sensitivity analysis. 


\subsection{Validation}

The final classification was compared with the most recent NASA BA product (MCD64A C6) for common years $(2001$ - 2016). The confusion matrix of each model was calculated, in addition to commission and omission error and Dice coefficient.

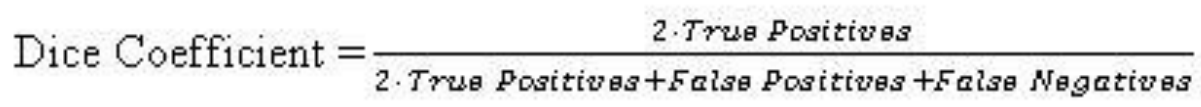

\section{Results}

The algorithm has been applied for whole time series (1981 - 2017). The product generated is the first to consistently offer such long time series, doubling the current time series. The study of sensitivity and percentage improve significantly the results.

The months with high fire occurrence obtained better results than months with low fire occurrence. Omission and commission errors were found quite balanced in the time series. Specifically, commission and omission error for the month of January is 0.53 and 0.47 and July is 0.49 and 0.57 , respectively. Average Dice coefficients were 0.50 for January and 0.46 for July. The best month was December (Figure 1) with 0.41 in commission error, 0.43 as omission error and a Dice coefficients of 0.58 .

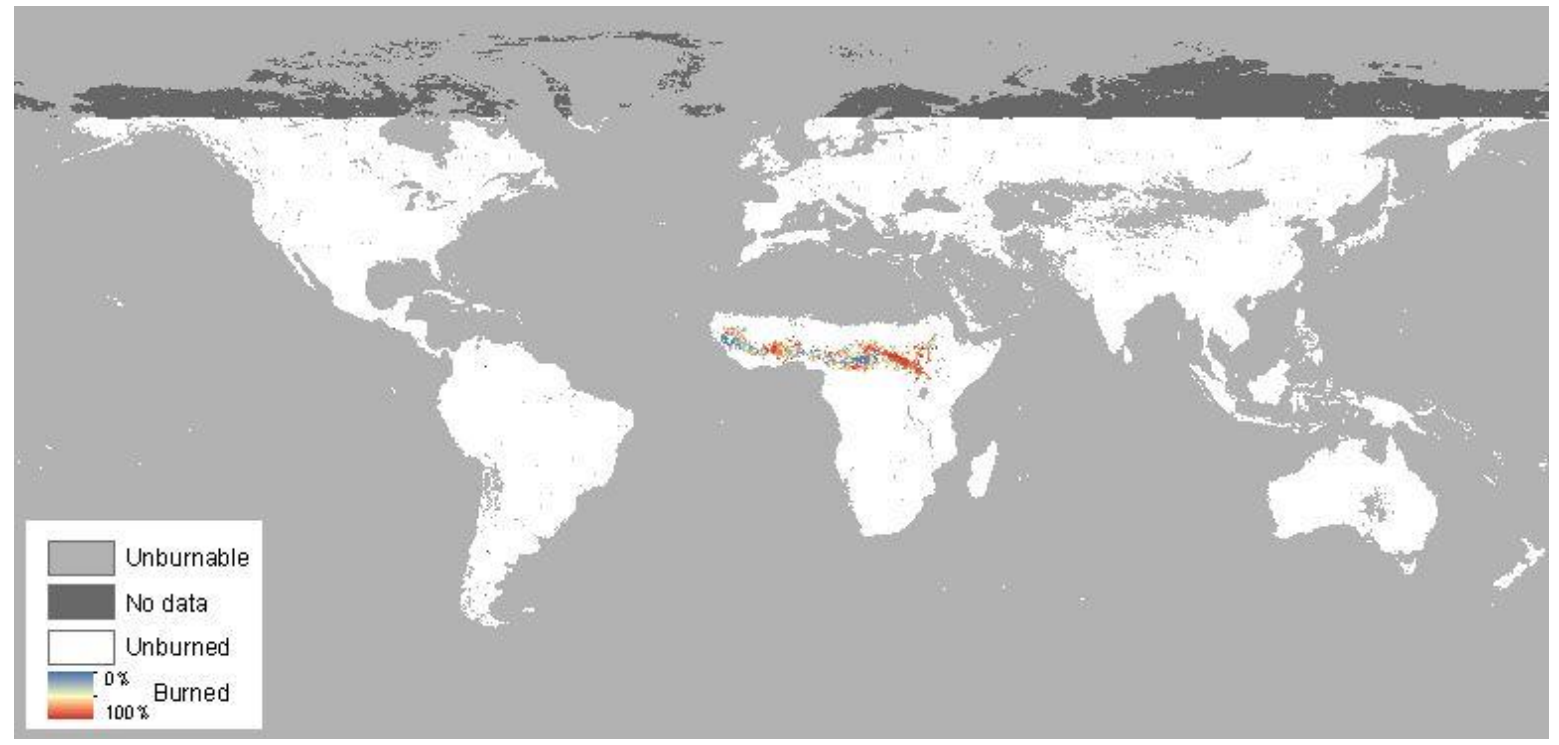

Figure 1 - Percentage BA of LTDR data for December 2008

\section{Bibliography}

Breiman, L. (2001). Random forests. Machine learning, 45, 5-32

Chuvieco, E., Ventura, G., Martín, M.P., \& Gomez, I. (2005). Assessment of multitemporal compositing techniques of MODIS and AVHRR images for burned land mapping. Remote Sensing of Environment, 94, 450 - 462

Giglio, L., Loboda, T., Roy, D.P., Quayle, B., \& Justice, C.O. (2009). An active-fire based burned area mapping algorithm for the MODIS sensor. Remote Sensing of Environment, 113, 408-420

Hantson, S., Arneth, A., Harrison, S.P., Kelley, D.I., Prentice, I.C., Rabin, S.S., Archibald, S., Mouillot, F., Arnold, S.R., \& Artaxo, P. (2016). The status and challenge of global fire modelling. Biogeosciences, 13, 3359-3375 
Kirches, G., Krueger, O., Boettcher, M., Bontemps, S., Lamarche, C., Verheggen, A., Lembrée, C., Radoux, J., \& Defourny, P. (2013). "Land Cover CCI: Algorithm Theoretical Basis Document Version 2.". Land_Cover_CCI_ATBDv2_2.3., Louvain, Belgium, 191 pp. Available at http://www.esa-landcovercci.org/?q=documents\#.

Martín, M.P., \& Chuvieco, E. (1998). Cartografía de grandes incendios forestales en la Península Ibérica a partir de imágenes NOAA-AVHRR. Serie Geográfica, 7, 109-128

Mouillot, F., Schultz, M.G., Yue, C., Cadule, P., Tansey, K., Ciais, P., \& Chuvieco, E. (2014). Ten years of global burned area products from spaceborne remote sensing-A review: Analysis of user needs and recommendations for future developments. International Journal of Applied Earth Observation and Geoinformation, 26, 64-79

Pedelty, J., Devadiga, S., Masuoka, E., Brown, M., Pinzon, J., Tucker, C., Vermote, E., Prince, S., Nagol, J., \& Justice, C. (2007). Generating a long-term land data record from the AVHRR and MODIS instruments. In, Geoscience and Remote Sensing Symposium, 2007. IGARSS 2007. IEEE International (pp. 1021-1025): IEEE

Pinty, B., \& Verstraete, M.M. (1992). GEMI: a non-linear index to monitor global vegetation from satellites. Vegetatio, 101, 15-20 